\title{
НЕБЕЗПЕКА НЕКОНТРОЛЬОВАНОГО САМОЛІКУВАННЯ ЧЕРЕЗ РОЗВИТОК АЛЕРГІЧНИХ РЕАКЦІЙ В СУДОВО-МЕДИЧНОМУ ЗНАЧЕННІ
}

\author{
Ясницька Е.Г.
}

Науковий керівник - к.м.н., Федорова О.А., кафедра судової медицини та медичного права Завідувач кафедри - д.м.н., проф. Б.В. Михайличенко

Національний медичний університет імені О.О. Богомольия

Анотація. Встановлення наявності алергічного стану у пацієнта до сих пір являє певні труднощі під час судово-медичної діагностики при проведенні експертиз трупів і потерпілих, обвинувачених та інших осіб. Офіційна статистика стверджує, що 69\% пацієнтів в Україні займається неконтрольованим самолікуванням. Метою свого дослідження стало вивчення реальної загрози розвитку алергічних станів внаслідок неконтрольованого самолікування. При проведенні інтернет-анкетування було встановлено, що з 117 анкетованих 64\% займається самолікуванням, причому, 22,8\% з 57 пацієнтів займалися самолікуванням через дорожнечу, у $70 \%$ пацієнтів спостерігалося розвиток алергічних реакцій, в основному, у вигляді кропивниці (15 , 4\%); і набряку Квінке (5,1\%); і 15,4\% заявили про те, що алергеном були лікарські препарати: антибіотики, сульфаніламіди пролонгованої дії, піразолонових похідні, барбітурати. Для зменшення ризиків розвитку алергічних реакцій рекомендується прискорити роботу по трансформації неконтрольованого самолікування в відповідальне.

Ключові слова: алергічні реакції, неконтрольоване самолікування, судово-медична діагностика

Вступ. Іноді перед судово-медичним експертом постає для вирішення питання про правильність проведеного лікування, або про те, чи можливо було б уникнути тяжких наслідків чи смерті при правильно проведеному лікуванні. Проте, такі питання повинні цікавити й лікарів інших спеціальностей, бо саме вони несуть відповідальність за якість лікування.

Встановлення алергічного стану у пацієнта, який лишився живим після розвитку алергічної реакції (АР), або помер, відноситься до складних питань судово-медичної діагностики. Схожість клінічних проявів при алергії та деяких захворюваннях (геморагічний васкуліт тощо) створює труднощі під час дифдіагностики. Також, іноді, перед судовомедичним експертом постає питання про правильність проведеного лікування пацієнта, про можливість уникнення тяжких наслідків чи смерті при адекватно проведеному лікуванні. Тому, при спірних причинах настання непередбачуваної смерті завжди спершу повинно бути вирішене питання про наявність або відсутність алергічного стану в судово-медичному значенні.

Проте, такі питання повинні цікавити й лікарів інших спеціальностей, бо саме вони несуть відповідальність за якість лікування.

Однак, яку відповідь може надати фахівець, якщо пацієнт, насправді, займався самолікуванням? Про те, що займатись самолікуванням не варто, постійно попереджають медики та МO3.

Ми вирішили дізнатись, чи справді самолікування становить серйозну небезпеку для життя та здоров'я пацієнтів. Самолікування розповсюджене по всьому світу. I ця проблема у країнах із розвиненою системою охорони здоров'я не стоїть надто гостро, оскільки, у вільному 
доступі є незначна кількість ліків, а їх реклама жорстко регламентована і спрямована не на пацієнта, а на лікарів.

Ставлення до самолікування в лікарів різне. Деякі країни заохочують відповідальне самолікування, наприклад, проводять випробування медпрепаратів в рамках самолікування. При цьому, пацієнти лікуються на основі рекомендацій лікарів. Наприклад, у Великій Британії відповідальне самолікування є важелем зменшення навантаження на систему охорони здоров'я. Це насамперед стосується більшості «хроніків». 70-80\% 3 них можуть контролювати свій стан самостійно, варто лише навчити їх цьому.

У країні діють державні та місцеві програми підтримки та навчання людей із хронічними захворюваннями. У рамках цих програм медики, соціальні працівники та волонтери навчають пацієнтів слідкувати за своїми показниками, нормалізувати свій стан 3 допомогою рекомендованих препаратів, вправ чи дієт, забезпечують (чи сприяють забезпеченню) ліками, апаратами для вимірювання тиску, тест-системами для вимірювання цукру.

Відповідальне самолікування розвантажує систему охорони здоров'я у Великій Британії i в деяких інших країнах. Воно здійснюється в рамках державних програм навчання людей із хронічними захворюваннями. Медики, волонтери й соціальні працівники навчають пацієнтів слідкувати за своїми показниками, нормалізувати свій стан 3 допомогою рекомендованих препаратів, вправ чи дієт, забезпечують апаратами для вимірювання тиску, тестсистемами для вимірювання цукру, ліками тощо.

Актуальність. В нашій країні здебільш розповсюджене неконтрольоване самолікування. Одним $з$ видів небезпеки, яку несе за собою неконтрольоване самолікування, $є$ розвиток алергічних реакцій (АР). I саме воно несе реальну загрозу життю пацієнтів. Щороку в Україні офіційно реєструється близько 500 нових випадків побічних реакцій різного ступеня важкості, які виникли в результаті самолікування.

В рамках реформування практичної медицини в нашій країні, на найвищому рівні вже, дуже вчасно, ініціюються проекти про впровадження закордонного досвіду в питаннях формування відповідального самолікування та більш ефективного контролю за рекламою ліків у засобах масової інформації [1].

Тому, зважаючи на кількість хворих, які обирають самолікування, обрана тема нашого дослідження є актуальною.

Метою роботи стало дослідження реальної небезпеки неконтрольованого самолікування через розвиток АР.

Матеріали роботи: статистичні дані зі 3МI, результати власного інтернет-анкетування.

Методи: анкето-опитувальний, порівняльний та аналітичний методи.

Для вирішення поставленої мети, нами були визначили такі етапи роботи:

- розробка анкетування,

- аналіз отриманих результатів

- виявлення найбільш небезпечних джерел алергенів

- визначення тяжких для здоров'я наслідків самолікування (АР)

- $\quad$ розробка шляхів зменшення небезпеки для пацієнтів.

Результати. Спочатку ми вирішили перевірити реальні масштаби самолікування та чи співпадають вони з даними офіційної статистики.

Згідно офіційному дослідженню, 69\% українців займаються самолікуванням через нестачу коштів [2]!

Малозабезпечені верстви населення надають перевагу неконтрольованому самолікуванню, не звертаючи увагу на зазначені протипоказання та можливі побічні АP. Цьому існують зрозумілі пояснення: дорогі ціни на ліки, недовіра до компетентності лікарів, 
інтернет-заклики про лікування «лише природними ліками». Тому, кількість випадків АР на лікарські препарати зростає. В Україні, за офіційними даними, страждає на алергією близько 10 млн осіб, тільки на ліки - 1,2 \% населення, а серед населення Франції, Англії, США вона досягає 5-12\% [3]. Згідно вітчизняної статистики, протягом 1990-2005 p. p. в Україні серйозних АР було зафіксовано 20,1\%, з яких 1,2\% закінчилися летально. Однак, справжня статистика таких випадків невідома, бо частина потенційних пацієнтів навіть не знає про те, що в них є алергія на ліки.

Нами була розроблена анкета та проведене інтернет-анкетування пересічних пацієнтів. В анкетуванні прийняли участь 117 осіб. Серед них, 93,2 \% складали пацієнти молодого віку (1944 років).

96 осіб з опитаних дали відповіді про власний спосіб лікування (рис. 1).

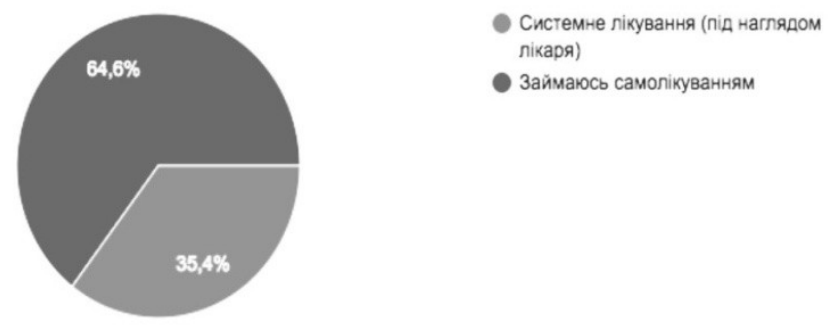

\section{Рис.1. Спосіб лікування}

Отже, 64 \% опитаних визнали, що лікуються самостійно. Тобто, отримані нами результати були наближені до статистики по Україні - в обох випадках виявилось, що самолікуванням займалось понад 60 \% пацієнтів.

57 анкетованих відповіли про причини самолікування, серед яких: найбільшу частку склала невпевненість у компетенції лікарів, дорогі ліки, сумніви в ефективності прописаних ліків (рис. 2).
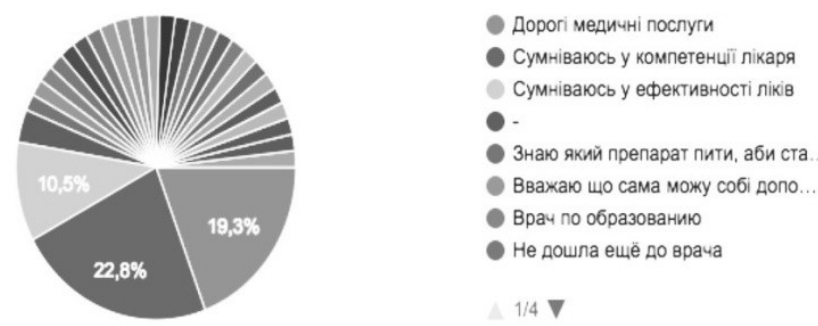

\section{Рис.2. Причини самолікування}

Наступним етапом дослідження стало визначення основних алергенів, внаслідок чого майже 30\% опитаних (3 117 опитаних) заперечували розвиток АР, 70 \% підтверджували, а 15,4\% з цих відповіли, що у них АР спричиняли ліки (рис. 3).

Основними алергенами, за відповідями опитуваних, були: антибіотики, сульфаніламіди пролонгованої дії, піразолонові похідні, барбітурати.

Опитані повідомили, що основними ускладненнями самолікування були:

- розвиток набряку Квінке в 5,1\% таких випадків

- розвиток кропив'янки в $15,4 \%$. 
Небезпеку набряку Квінке (Т 78.0) становить стеноз та набряк гортані, через які в людини може розви нутись стан механічної асфіксії.

\section{Чи були у Вас алергічні захворювання? Якщо так, то які? (можна вказати декілька варіантів)}

\section{7 ответов}

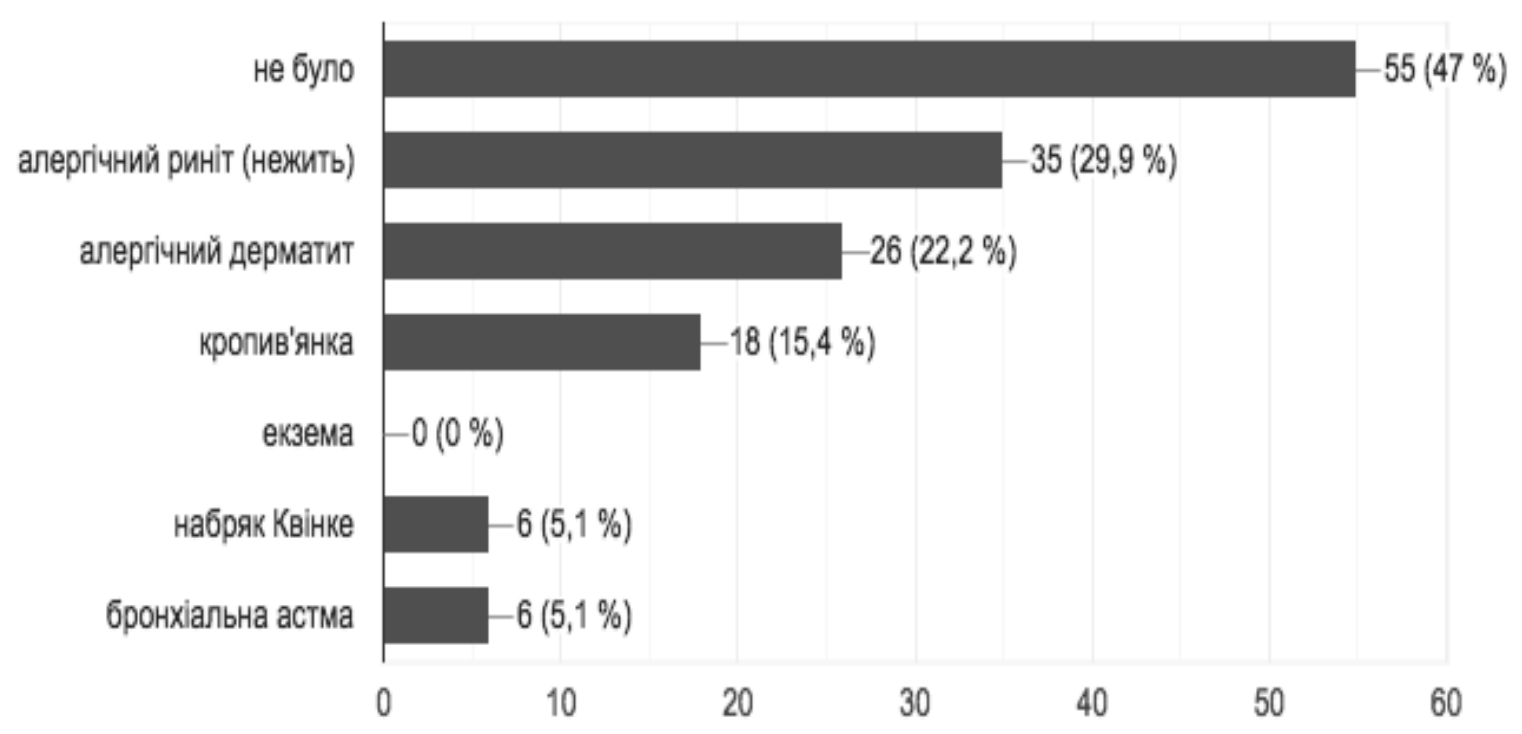

Окрім того, деякі пацієнти повідомляли про появу таких нестійких ознак анафілактичної реакціі, як задуха, зміна кольору шкіри, зуд. 


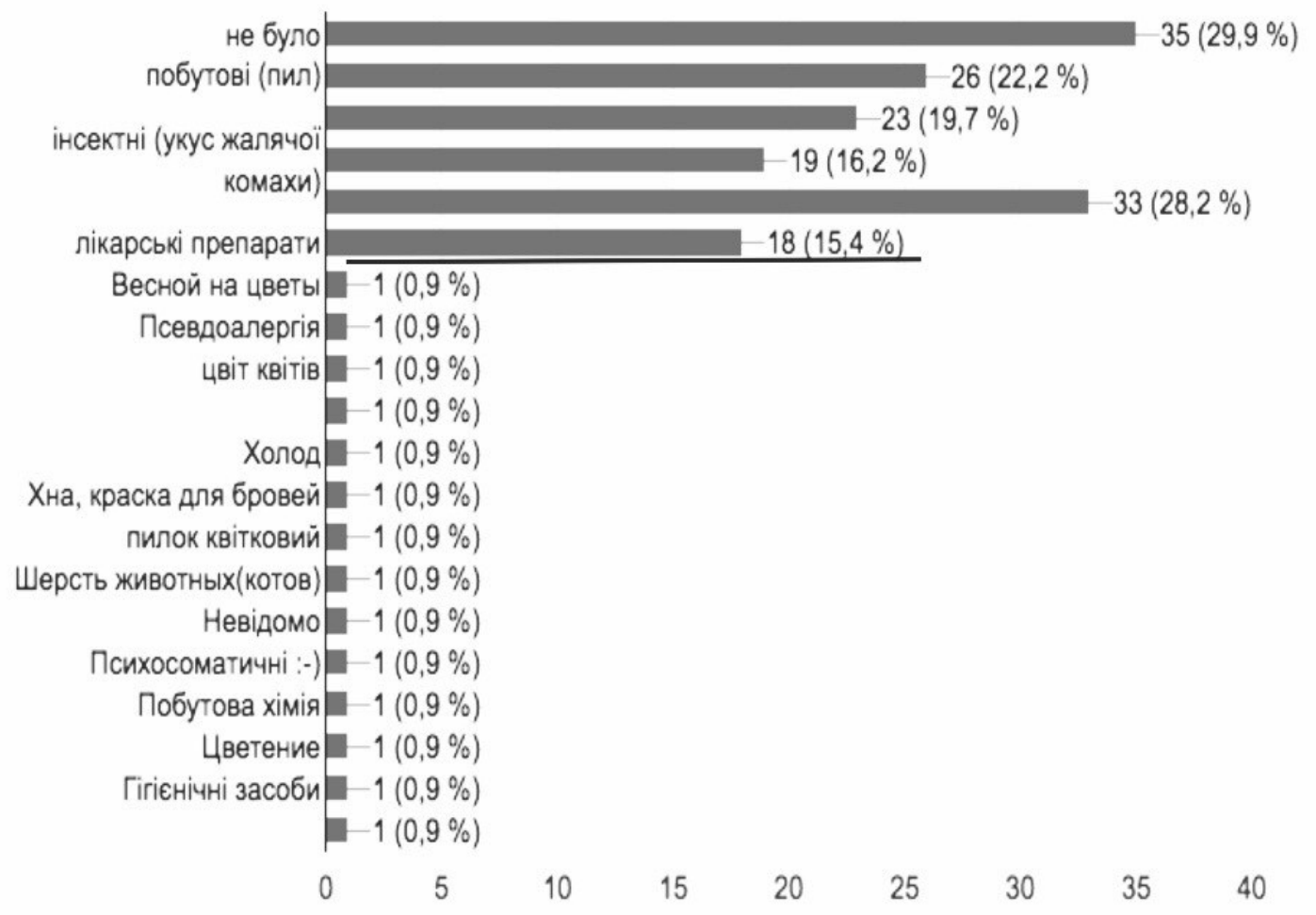

\section{Рис. 3. Наявність алергічних реакцій на певний алерген}

Зазвичай, клінічними проявами медикаментозної алергії є різноманітні зміни крові (клітин лейкоцитарного ряду, тромбоцитів, еритроцитів, змін у сироватці), висипи та набряки на шкірі, підвищення температури та враження органів та систем. Слід пам'ятати, що всім відома еозинофілія, яка супроводжує кропив'янку, висипи та артралгії зустрічається й при неспецифічних запальних процесах у внутрішніх органах, особливо, в легенях. 3 відміною прийому препарату, що містить алерген, зміни крові можуть дуже швидко минути. АР, які мали швидкий перебіг, зазвичай, не змінювали ШОЕ. Тому, при проведенні дифдіагностики, слід ретельно враховувати всі клінічні та інші (морфологічні тощо) дані.

Однак, при судово-медичній діагностиці смерті внаслідок розвитку АР, окрім вище перелічених ознак, додається виявлення: масивного внутрішнього набряку тканин, закупорки бронхів слизом, змін тонусу та некрозів мілких судин, дрібних крововиливів в слизові та під серозні оболонки, гострої дистрофії клітин паренхіматозних органів тощо.

Отже, ми встановили, що в нашій країні, в межах нашого дослідження, дійсно, переважало неконтрольоване самолікування.

Таким чином, на основі власного проведеного дослідження проблеми небезпеки для життя пацієнтів через ризики виникнення АР внаслідок неконтрольованого самолікування та вивчення відповідної медичної літератури, ми дійшли висновку, що дана проблема продовжує залишатись на даний час актуальною.

\section{Висновок}

Для зменшення летальності та розвитку тяжких ускладнень внаслідок неконтрольованого самолікування пропонуємо: на державному рівні посилити заходи для переведення неконтрольованого виду самолікування в контрольований та ефективніше контролювати рекламу лікарських засобів, які є у вільному продажу, посилити пропаганду основних знань 3 
алергології; інформувати населення про фатальні (летальні) випадки самолікування та способи надання першої необхідної допомоги.

Конфлікт інтересів. Конфлікт інтересів не заявляється.

Джерела фінансування. "Це дослідження не отримало ніякої фінансової підтримки від державної, громадської чи комерційної організацї̈. Дослідження проведене власним коштом.

Рецензент: д. мед. н., проф. Б.В. Михайличенко

\section{ЛIТЕРАТУРА}

1. Нові вимоги до реклами лікарських засобів - МОЗ України презентує законопроект [Електронний ресурс] - Режим доступу: https://www.apteka.ua/article/457682

2. У. Супрун. Самолечение в Украине [Електронний ресурс] - Режим доступу: https://censor.net.ua/n458721 (№ 20 (1141) від 21.05.2018 p.)

3. Скільки людей страждає на медикаментозну алергію. Електронний доступ до pecypcy: http://103fm.com.ua/med/15220-2010-12-16-11-03-28.html

\section{REFERENCES}

1. Novi vymohy do reklamy likars'kykh zasobiv - MOZ Ukrayiny prezentuye zakonoproekt [Elektronnyy resurs] - Rezhym dostupu: https://www.apteka.ua/article/457682

2. U. Suprun Samolechenye v Ukrayne [Elektronnyy resurs] - Rezhym dostupu: https://censor.net.ua/n458721 (№ 20 (1141) vid 21.05.2018 r.)

3. Skil'ky lyudey strazhdaye na medykamentoznu alerhiyu. Elektronnyy dostup do resursu: http:// 103fm.com.ua/med/15220-2010-12-16-11-03-28.html

\section{ОПАСНОСТЬ НЕКОНТРОЛИРУЕМОГО САМОЛЕЧЕНИЯ ИЗ-ЗА РАЗВИТИЯ АЛЛЕРГИЧЕСКИХ РЕАКЦИЙ В СУДЕБНО-МЕДИЦИНСКОМ ЗНАЧЕНИИ}

Установление наличия аллергического состояния у пациента до сих пор представляет определенные трудности во время судебно-медицинской диагностики при проведении экспертиз трупов и потерпевших, обвиняемых и др. лиц. Официальная статистика утверждает, что $69 \%$ пациентов в Украине занимается неконтролируемым самолечением. Целью собственного исследования стало изучение реальной угрозы развития аллергических состояний вследствие неконтролируемого самолечения. При проведении интернет-анкетирования было установлено, что из 117 анкетируемых 64 \% занимается самолечением, причем, 22,8 \% из 57 пациентов занимались самолечением из-за дороговизны, у 70\% пациентов наблюдалось развитие аллергических реакций, в основном, в виде крапивницы $(15,4 \%)$; и отёка Квинке $(5,1 \%)$; и 15,4 \% заявили о том, что аллергеном являлись лекарственные препараты: антибиотики, сульфаниламиды пролонгированного действия, пиразолоновые производные, барбитураты. Для уменьшения рисков развития аллергических реакций рекомендуется ускорить работу по трансформации неконтролируемого самолечения в ответственное.

Ключевые слова: аллергические реакции, неконтролируемое самолечение, судебномедицинская диагностика. 


\section{DANGER OF UNCONTROLLABLE SELF-TREATMENT DUE TO THE DEVELOPMENT OF ALLERGIC REACTIONS IN FORENSIC MEDICAL VALUE}

The determination of the presence of an allergic condition in a patient still presents certain difficulties during forensic diagnostics during examinations of corpses and victims, the accused, and others. According to official statistics, $69 \%$ of patients in Ukraine are engaged in uncontrolled selfmedication. The purpose of his own research was to study the real threat of the development of allergic conditions due to uncontrolled self-medication. During the online survey, it was found that out of 117 surveyed $64 \%$ engaged in self-treatment, and $22.8 \%$ of 57 patients were self-treating due to the high cost, $70 \%$ of patients experienced allergic reactions, mainly in the form of urticaria (15,four\%); and angioedema (5.1\%); and $15.4 \%$ said that the allergen was drugs: antibiotics, long-acting sulfonamides, pyrazolone derivatives, barbiturates. To reduce the risk of allergic reactions, it is recommended to speed up the work on the transformation of uncontrolled self-medication into a responsible one.

Key words: allergic reactions, uncontrolled self-medication, forensic medical diagnostics. 